\title{
Hematology values of captive giant anteaters (Myrmecophaga tridactyla) and collared anteaters (Tamandua tetradactyla) ${ }^{1}$
}

\author{
Thaís C. Sanches ${ }^{2 *}$, Flávia R. Miranda ${ }^{3}$, Alice S. Oliveira ${ }^{4}$ and Eliana R. Matushima ${ }^{5}$ \\ ABSTRACT.- Sanches T.C., Miranda F.R., Oliveira A.S. \& Matushima E.R. 2013. Hematology \\ values of captive giant anteaters (Myrmecophaga tridactyla) and collared anteaters \\ (Tamandua tetradactyla). Pesquisa Veterinária Brasileira 33(4):557-560. Programa de \\ Pós-Graduação em Patologia Experimental e Comparada, Faculdade de Medicina Veteriná- \\ ria e Zootecnia, Universidade de São Paulo, Av. Prof. Dr. Orlando Marques de Paiva 87, São \\ Paulo, SP 05508-270, Brazil. E-mail: tatasanches@uol.com.br \\ Hematological results are reported for 13 giant anteaters (Myrmecophaga tridactyla) \\ and 13 collared anteaters (Tamandua tetradactyla). Animals were captive-reared adults \\ held at the Fundação Parque Zoológico de São Paulo (São Paulo, SP, Brazil) and Parque Zo- \\ ológico Municipal Quinzinho de Barros (Sorocaba, SP, Brazil), and were considered healthy \\ on physical examination. Examined parameters included red blood cell count, white blood \\ cell count, hematocrit, hemoglobin concentration, mean corpuscular volume, mean cor- \\ puscular hemoglobin, mean corpuscular hemoglobin concentration, total plasmatic pro- \\ tein and differential leukocyte counts. Also, a survey for hemoparasites was done and none \\ was observed in thin blood smears. The results were generally similar to those previously \\ reported in the exiguous literature for these species, providing further reference data for \\ the interpretation of laboratory results besides health monitoring, assisting early disease \\ diagnosis and providing relevant information for conservation programs for these species.
}

INDEX TERMS: Collared anteater, giant anteater, hematology, Myrmecophaga tridactyla, reference values, Tamandua tetradactyla.

RESUMO.- [Valores hematológicos de tamanduá-bandeira (Myrmecophaga tridactyla) e tamanduá-mirim (Tamandua tetradactyla) oriundos de cativeiro.] Obteve-se os valores hematológicos de 13 tamanduás-bandeira (Myrmecophaga tridactyla) e 13 tamanduás-mirim (Tamandua tetradactyla) adultos e saudáveis segundo exame físico, oriundos de cativeiro, da Fundação Parque Zoológico de São Paulo (São Paulo) e do Parque Zoológico Municipal Quinzinho de Barros (Sorocaba). Os parâmetros hematológicos estudados incluíram contagem total de eritrócitos e leucócitos, hematócrito, concentração de hemoglobina, vo-

\footnotetext{
${ }^{1}$ Received on August 8, 2012.

Accepted for publication on March 20, 2013.

${ }^{2}$ Programa de Pós-Graduação em Patologia Experimental e Comparada, Faculdade de Medicina Veterinária e Zootecnia (FMVZ), Universidade de São Paulo (USP), Av. Prof. Dr. Orlando Marques de Paiva 87, Cidade Universitária, São Paulo, SP 05508-270, Brazil. *Corresponding author: tatasanches@uol.com.br

${ }^{3}$ Projeto Tamanduá, Wildlife Conservation Society, Alameda João de Barro 420, Mairiporã, SP 07600-000, Brazil.

${ }^{4}$ Iniciação científica, FMVZ-USP, São Paulo, SP.

${ }^{5}$ Departamento de Patologia, FMVZ-USP, São Paulo, SP.
}

lume corpuscular médio, hemoglobina corpuscular média, concentração de hemoglobina corpuscular média, proteína plasmática total estimada e contagem diferencial de leucócitos. Também se realizou a pesquisa de hemoparasitas, não se encontrando nenhum nos esfregaços sanguíneos. De maneira geral, os valores obtidos não diferiram muito daqueles presentes na pouca literatura existente, contribuindo com dados adicionais para a interpretação de resultados laboratoriais, visando acompanhamento do estado sanitário, auxílio no diagnóstico de enfermidades e programas de conservação dessas espécies.

TERMOS DE INDEXAÇÃO: Tamanduá-bandeira, tamanduá-mirim, hematologia, Myrmecophaga tridactyla, valores de referência, Tamandua tetradactyla.

\section{INTRODUCTION}

Anteaters are mammals belonging to the Order Pilosa, Superorder Xenartha, and their geographic distribution is limited to the Central and South Americas. Giant anteaters (Myrmecophaga tridactyla) and collared anteaters (Tamandua tetradactyla) occur in most Brazilian biomes, 
as Amazon, Caatinga, Cerrado, Atlantic forest and Pantanal (Fonseca et al. 1996).

The intense human activities of natural resource exploitation in Brazil have led to extensive habitat loss, degradation and fragmentation, constituting the major threats for the conservation of terrestrial mammals in the country (Costa et al. 2005). The consequences can already be perceived for Myrmecophaga tridactyla, which is classified as "vulnerable" in the Brazilian Official List of Species Threatened with Extinction (Brasil, 2003) and "near threatened" in the IUCN Red List of Threatened Species Version 2010.1, and since 2003 is included in the Appendix II of the Convention on International Trade in Endangered Species of Wild Fauna and Flora (CITES).

Although there is a known need of conservation efforts for these species and of a better knowledge on the health status of captive specimens, information on the major illnesses of these animals or the reference values for laboratory exams that assist their diagnosis is still scarce in the literature. Hematology is an important tool for evaluating the health of wild animals, supporting the clinical diagnosis and the monitoring of apparently healthy individuals, and providing bioindicators for the early detection of environmental disturbs (Almosny \& Monteiro 2007, Santos \& Cubas 2007, Mckeown 2008). There is currently a scarcity of published data regarding the hematology of Myrmecophaga tridactyla and Tamandua tetradactyla. This study aims to present the hematological results of clinically healthy adult individuals of both anteater species, from captive-reared individuals held in zoos at the São Paulo state, Brazil.

\section{MATERIALS AND METHODS}

A total 13 giant anteaters (Myrmecophaga tridactyla) and 13 collared anteaters (Tamandua tetradactyla) were studied. Animals were captive-bred adults held at the Fundação Parque Zoológico de São Paulo (São Paulo, SP, Brazil) and Parque Zoológico Municipal Quinzinho de Barros (Sorocaba, SP, Brazil), and were considered healthy on physical examination.

To provide safe handling and sample collection, animals were chemically restrained with an intramuscular injection of ketamine chloridrate $(10 \mathrm{mg} / \mathrm{kg})$ and midazolam $(1 \mathrm{mg} / \mathrm{kg})$ (Miranda et al. 2006). Blood samples (1ml) were collected from the cephalic vein into sterile EDTA Vacutainer tubes (Becton-Dickison, USA) (Thrall 2007, Vietto et al. 2008). Thin blood smears were produced and air dried immediately after blood sampling, to avoid artifacts associated to the prolonged contact with anticoagulants. Remaining blood samples were stored under refrigeration $\left(8-12^{\circ} \mathrm{C}\right)$ and hematological analyses were performed within 24 hours (Rebar et al. 2003).

Blood samples were analyzed for the following parameters: red blood cell count (RBC), white blood cell count (WBC), hematocrit (Hct), total plasmatic protein (TPP), hemoglobin concentration ( $\mathrm{Hb}$ ), mean corpuscular volume (MCV), mean corpuscular hemoglobin $(\mathrm{MCH})$, mean corpuscular hemoglobin concentration (MCHC), and differential counts of neutrophils, eosinophils, basophils, lymphocytes and monocytes.

RBC and WBC were determined manually with a hemocytometer. A 1:200 dilution with Gower's solution (12.5g sodium sulfate, $33.3 \mathrm{ml}$ acetic acid, $200 \mathrm{ml}$ distilled water) was used to perform RBC counts; a 1:20 dilution with Turk's solution $(1.5 \mathrm{ml}$ acetic acid, $1 \mathrm{ml}$ gentian violet, $100 \mathrm{ml}$ distilled water) was used to perform WBC counts (Santos 1999). Red cells were counted within the five central square areas of the hemocytometer chamber, whereas white cells were counted within the four peripheral large squares of the chamber (Santos 1999). Hematocrit was determined by high speed centrifugation (11000 rpm, 5 minutes) of microcapillaries, and a refractometer was used to estimate total plasmatic protein from the microcapillaries' plasma. Hemoglobin concentration was determined by the cyanmethemoglobin method using a semi-automated bioanalyzer (Bioplus ${ }^{\circledR}$ BIO 200). Differential leukocyte counts were carried out using thin blood smears stained with a May-Grunwald-Giemsa stain modified by Rosenfeld (Rosenfeld 1947a, Rosenfeld 1947b), examining 100 leukocytes and categorizing them as neutrophils, eosinophils, basophils, lymphocytes or monocytes (Rebar et al. 2003, Thrall 2007). Moreover, each blood smear was examined for hemoparasites and morphologic or staining abnormalities of blood cells (Rebar et al. 2003, Thrall 2007).

Statistical analyses were performed using IBM SPSS Statistics 18 (IBM Company, Chicago, Illinois, USA). Mean, standard deviation and range were calculated for each hematological parameter. Comparisons among genders were not attempted because of the limited number of individuals.

Table 1. Hematology values for Myrmecophaga tridactyla $(n=13)$

\begin{tabular}{lccc}
\hline \multicolumn{1}{c}{ Parameter } & Mean & SD & Range \\
\hline RBC $\left(\times 10^{6} / \mu \mathrm{l}\right)$ & 2.36 & 0.14 & $2.05-2.67$ \\
$\mathrm{HCT}(\%)$ & 37.70 & 1.06 & $35.44-40.10$ \\
$\mathrm{Hb}(\mathrm{g} / \mathrm{dl})$ & 11.80 & 0.52 & $10.60-12.90$ \\
$\mathrm{MCV}(\mathrm{fl})$ & 165.12 & 8.71 & $146.12-184.11$ \\
$\mathrm{MCH}(\mathrm{pg})$ & 51.07 & 2.27 & $46.11-56.02$ \\
$\mathrm{MCHC}(\%)$ & 31.26 & 0.96 & $29.15-33.26$ \\
WBC $(\mathrm{x} \mathrm{10} / \mu \mathrm{l})$ & 11.87 & 2.88 & $5.59-18.14$ \\
Neutrophils $(\%)$ & 72.62 & 3.67 & $64.60-80.63$ \\
Absolute neutrophils $\left(\mathrm{x} 10^{3} / \mu \mathrm{l}\right)$ & 8.90 & 2.28 & $3.91-13.88$ \\
Eosinophils $(\%)$ & 6.92 & 1.67 & $3.29-10.56$ \\
Absolute eosinophils $\left(\mathrm{x} 10^{3} / \mu \mathrm{l}\right)$ & 0.97 & 0.40 & $0.08-1.86$ \\
Basophils $(\%)$ & 0 & 0 & 0 \\
Absolute basophils $\left(\mathrm{x} 10^{3} / \mu \mathrm{l}\right)$ & 0 & 0 & 0 \\
Lymphocytes $(\%)$ & 18.77 & 3.17 & $11.84-25.70$ \\
Absolute lymphocytes $\left(\mathrm{x} 10^{3} / \mu \mathrm{l}\right)$ & 1.80 & 0.33 & $1.07-2.53$ \\
Monocytes $(\%)$ & 1.69 & 0.04 & $0.09-0.29$ \\
Absolute monocytes $\left(\mathrm{x} 10^{3} / \mu \mathrm{l}\right)$ & 0.19 & 0.04 & $0.09-0.29$ \\
TP $(\mathrm{g} /$ dl) & 8.10 & 0.15 & $7.77-8.42$
\end{tabular}

Table 2. Hematology values for Tamandua tetradactyla $(n=13)$

\begin{tabular}{lccc}
\hline \multicolumn{1}{c}{ Parameter } & Mean & SD & Range \\
\hline RBC $\left(\times 10^{6} / \mu \mathrm{l}\right)$ & 3.15 & 0.23 & $2.63-3.67$ \\
$\mathrm{HCT}(\%)$ & 34.80 & 1.50 & $31.50-38.10$ \\
$\mathrm{Hb}(\mathrm{g} / \mathrm{dl})$ & 10.73 & 0.58 & $9.46-12.00$ \\
$\mathrm{MCV}(\mathrm{fl})$ & 116.06 & 7.46 & $99.79-132.32$ \\
$\mathrm{MCH}(\mathrm{pg})$ & 35.45 & 2.05 & $30.98-39.92$ \\
$\mathrm{MCHC}(\%)$ & 31.14 & 1.65 & $27.53-34.74$ \\
WBC $(\mathrm{x} \mathrm{10} / \mu \mathrm{l})$ & 8.07 & 1.04 & $5.79-10.34$ \\
Neutrophils $(\%)$ & 48.15 & 4.09 & $39.23-57.08$ \\
Absolute neutrophils $\left(\mathrm{x} 10^{3} / \mu \mathrm{l}\right)$ & 3.80 & 0.54 & $2.62-4.98$ \\
Eosinophils $(\%)$ & 5.69 & 0.88 & $3.78-7.61$ \\
Absolute eosinophils $\left(\mathrm{x} 10^{3} / \mu \mathrm{l}\right)$ & 0.45 & 0.10 & $0.22-0.68$ \\
Basophils $(\%)$ & 0 & 0 & 0 \\
Absolute basophils $\left(\mathrm{x} 10^{3} / \mu \mathrm{l}\right)$ & 0 & 0 & 0 \\
Lymphocytes $(\%)$ & 44.15 & 4.18 & $35.04-53.27$ \\
Absolute lymphocytes $\left(\mathrm{x} 10^{3} / \mu \mathrm{l}\right)$ & 3.65 & 0.64 & $2.24-5.06$ \\
Monocytes $(\%)$ & 2.00 & 0.35 & $1.22-2.78$ \\
Absolute monocytes $\left(\mathrm{x} 10^{3} / \mu \mathrm{l}\right)$ & 0.15 & 0.03 & $0.07-0.22$ \\
TP (g/dl) & 8.91 & 0.19 & $8.49-9.33$
\end{tabular}




\section{RESULTS}

The animals were considered healthy on physical examination, and the hematological results for Myrmecophaga tridactyla and Tamandua tetradactyla are presented respectively in Table 1 and 2. No hemoparasites were observed in the blood smears.

\section{DISCUSSION}

Published information on the hematological parameters of Myrmecophaga tridactyla and Tamandua tetradactyla is still scarce in the national and international literature (Rosenfeld \& Hoehne 1953, Santos 1999, ISIS 2002, Satake 2002, Gillespie 2003).

$\mathrm{RBC}$, hematocrit, hemoglobin concentration, $\mathrm{MCV}, \mathrm{MCH}$ and MCHC for M. tridactyla were generally similar to those reported by Satake (2002) and in the International Species Information System database (ISIS 2002), but were slightly divergent from those reported by Fowler \& Miller (2003) and Rosenfeld \& Hoehne (1953). It should be considered that the use of chemical restraint drugs may reduce the number of circulating erythrocytes due to blood pressure decreases and splenic sequestration (Satake 2002). The average WBC in our results were similar to those reported by Satake (2002), and were generally higher than those reported by Rosenfeld \& Hoehne (1953) and in the ISIS database (2002). Neutrophil counts were higher than those previously published, eosinophil counts were similar to those reported by Satake (2002) and Rosenfeld \& Hoehne (1953), lymphocyte and monocyte counts were coherent with those reported in the ISIS database (2002). Total plasmatic protein concentrations were similar to the findings of Satake (2002). In contrast with the aforementioned studies, band neutrophils and basophils were not observed.

In relation to T. tetradactyla, the $\mathrm{RBC}$ were consonant to those from the ISIS database (2002) while the remaining parameters presented slightly lower results, with the exception of total plasmatic protein which was slightly higher. Similarly to our results for $M$. tridactyla, band neutrophils and basophils were not observed in contrast to the published literature (ISIS 2002, Fowler \& Miller 2003).

In agreement with the findings reported in the ISIS database (2002) and by Fowler \& Miller (2003), lymphocyte counts were considerably higher in $T$. tetradactyla than in M. tridactyla. The blood cell morphology of anteaters is generally analogous to that of other mammals (Rosenfeld \& Hoehne 1953, Campbell 2007). A particular characteristic of $M$. tridactyla is that their erythrocytes are comparatively larger than those of other mammals (Divers 1986), including T. tetradactyla (Rosenfeld \& Hoehne 1953). Other particular aspects of these species' blood cells are the fine and nearly imperceptible appearance of the cytoplasmatic granules and the light-pink to blue cytoplasmatic staining in the segmented neutrophils, and the subtlety of the intracytoplasmatic granulations in the eosinophils, characteristics previously noted by Rosenfeld \& Hoehne (1953).

There are few studies on the prevalence of hemoparasites in anteaters. None were observed in this study, simi- larly to Ayala et al. (1973) and Renjifo et al. (1952). On the other hand, Thoisy et al. (2000) found trypanosomatids in $19(44 \%)$ and filarids in $17(40 \%)$ of a total 43 free-ranging T. tetradactyla. Dereure et al. (2001) also isolated Trypanosoma legeri from the blood of a free-ranging Tamandua tetradactyla.

Future studies may reveal significant statistical differences of hematological parameters among genders, which were not examined in this study due to the limited sample sizes. The comparison of hematological results among genders, age groups, nutritional conditions, habitats and other factors is relevant and should be carried out whenever there is sufficient available data.

\section{CONCLUSIONS}

Hematology is an essential tool for wildlife medicine and conservation, as it provides relevant information on the individuals' health status, assists the diagnosis and monitoring of disease, and eventually is also a useful resource for a variety of studies and applications in species conservation.

Just as laboratory exams are part of the clinical routine in domestic animal practice, their use should also be encouraged in wildlife medicine.

Hematological studies of healthy captive animals are essential as they provide data that may be useful in the interpretation of laboratory exams and encourage wildlife veterinarians to use these resources as diagnostic assets to evaluate the health status of free-ranging and captive animals, as well as in reintroduction programs.

The gathering of data regarding the national fauna must be encouraged as it reflects our environmental conditions, either in captivity or in the wild, which may often differ from those of other countries. For this reason, further well-structured studies are advised.

The results presented here may be used as a panel of hematologic data for Myrmecophaga tridactyla and Tamandua tetradactyla and, along with the remaining published literature, can be used as reference values for the interpretation of laboratory exams for these species.

Acknowledgments.- To the technicians of Fundação Parque Zoológico de São Paulo e Parque Zoológico Municipal Quinzinho de Barros for helping with the animals and Anteater Project (www.tamandua.org).

\section{REFERENCES}

Almosny N.R.P. \& Monteiro A.O. 2007. Patologia clínica, p.939-966. In: Cubas Z.S., Silva J.C.R. \& Catão-Dias J.L. (Eds), Tratado de Animais Selvagens: medicina veterinária. Roca, São Paulo. 1354p.

Ayala S.C., D’Alessandro A., Mackenzie R. \& Angel D. 1973. Hemoparasite infections in 830 animals from the eastern llanos of Colombia. J. Parasitol. 59(1):52-59.

Brasil. Ministério do Meio Ambiente 2003. Instrução Normativa no 03 de 27 de maio de 2003. Lista vermelha de espécies da fauna brasileira ameaçadas de extinção. Diário Oficial, Brasília, 27 de Maio 2003.

Campbell T.W. 2007. Hematologia de mamíferos: animais de laboratório e espécies variadas, p.201-214. In: Thrall M.A. (Ed.), Hematologia e Bioquímica Clínica Veterinária. Roca, São Paulo. 582p.

Costa L.P., Leite Y.L.R., Mendes S.L. \& Distchfield A.D. 2005. Conservação de mamíferos do Brasil. Megadiversidade 1(1):103-112. 
Dereure J., Barnabé C., Vié J.C., Madélenat F. \& Raccurt C. 2001. Trypanosomatidae from wild mammals in the neotropical rainforest of French Guiana. Annals Trop. Med. Parasitol. 95(2):157-166.

Divers B.J. 1986. Edentata, p. 621-630. In: Fowler M.E. \& Pedersen D. (Eds), Zoo and Wild Animal Medicine. W.B. Saunders Company, Philadelphia. $1127 p$.

Fonseca G.A.B., Hermann G., Leite Y.L.R., Mittermeier R.A., Rylands A.B. \& Patton J.L. 1996. Lista anotada de mamíferos do Brasil. Occasional Papers in Conservation Biology 4:1-38.

Gisllespie D. 1986. Xenarthra (Edentata), p.397-407. In: Fowler M.E. \& Miller R.E. (Eds), Zoo and Wild Animal Medicine. W.B. Saunders, St Louis. $1127 \mathrm{p}$.

ISIS 2002. International Species Information System, USA. (CD-ROM)

IUCN 2007. Red list of threatened species. The Internacional Union for the Conservation of Nature and Natural Resources Disponível em <http:// www.iucnredlist.org> Acessed July 10, 2010.

McKeown B. 2008. The art and mechanics of the in-house hemogram. Proc. Association of Avian Veterinarians, California, p.97-101.

Miranda F.R., Solis G., Superina M. \& Jiménez I. 2006. Manual clínico para el manejo del oso hormiguero gigante (Myrmecophaga tridactyla). Manual Técnico. 26p.

Rebar A.H., MacWilliams P.S., Feldman B.F., Metzger F.L., Pollock R.V.H. \& Roche J. 2003. Guia de Hematologia para Cães e Gatos. Roca, São Paulo. 291p.

Renjifo S., Sanmartín C. \& Zulueta J. 1952. A survey of the blood parasites of vertebrates in Eastern Columbia. Acta Tropica 9(2):151-169.

Rosenfeld G. 1947a. A Corante pancrômico para hematologia e citologia clínica: nova combinação dos componentes do May-Grünwald e do
Giemsa num só corante de emprego rápido. Mem. Inst. Butantan 20: 329-334.

Rosenfeld G. 1947b. Método rápido de coloração de esfregaços de sangue. Noções práticas sobre corantes pancrômicos e estudo de diversos fatores. Mem. Inst. Butantan 20:315-328.

Rosenfeld G. \& Hoehne L. 1953. Studies on comparative hematology - I. Hematologic data of Myrmecophaga t. tridactyla L., 1758 (Tamaduá-bandeira) and Tamandua t. tetradactyla L., 1758 (Tamanduá-mirim). Mem. Inst. Butantan 25(1):41-52.

Santos L.C. 1999. Valores de referência para exames laboratoriais, p.240. In: Ibid. (Ed.), Laboratório Ambiental. Editora Universitária, Cascavel. 323p.

Santos L.C. \& Cubas P.H. 2007. Coleta e conservação de amostras biológicas, p.930-938. In: Cubas Z.S., Silva J.C.R. \& Catão-Dias J.L. (Eds), Tratado de Animais Selvagens: medicina veterinária. Roca, São Paulo. 1354p.

Satake F. 2002. Hemograma e constituintes bioquímicos do sangue de tamanduás-bandeira (Myrmecophaga tridactyla) de vida livre e de cativeiro. Dissertação de Mestrado em Medicina Veterinária, Faculdade de Medicina Veterinária e Zootecnia, Universidade Estadual Paulista Júlio de Mesquita Filho, Jaboticabal, SP. 54p.

Thoisy B., Mitchel J.C., Vogel I. \& Vié J.C. 2000. A survey of hemoparasite infections in free-ranging mammals and reptiles in French Guiana. J. Parasitol. 86(5):1035-1040.

Thrall M.A. 2007. Morfologia das hemácias, p.65-77. In: Ibid. (Ed.), Hematologia e Bioquímica, Clínica Veterinária. Roca, São Paulo. 582p.

Vietto N., Carlín M.C. \& Cerutti P.A. 2008. Caracterización morfológica de los elementos figurados de la sangre de Myrmecophaga tridactyla. Proyeto Conservacion Oso Hormiguero Gigante, Buenos Aires. Disponível em <http://www.proyectoosohormiguero.org/ElOso_Investigacion. htm> Acessed June 10, 2010. 